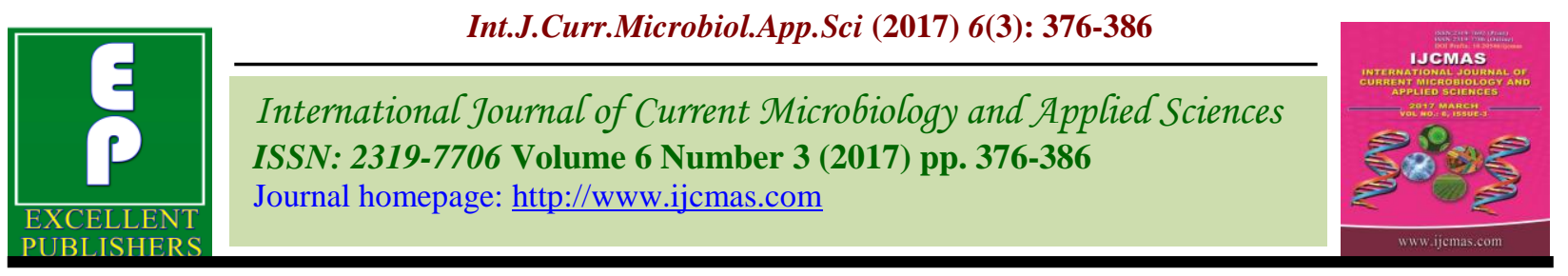

Original Research Article

https://doi.org/10.20546/ijcmas.2017.603.043

\title{
Protein, Micronutrient, Antioxidant Potential and Phytate Content of Pearl Millet Hybrids and Composites Adopted for Cultivation by Farmers of Haryana, India
}

\author{
M.K. Berwal ${ }^{1}$, L.K. Chugh ${ }^{2}$, Preeti Goyal ${ }^{3}$, Ramesh Kumar ${ }^{2}$ and Dev $\operatorname{Vart}^{2}$ \\ ${ }^{1}$ ICAR-Central Institute for Arid Horticulture, Bikaner, India \\ ${ }^{2}$ Bajra Section, Department of Genetics and Plant Breeding, CCS HAU Hisar, India \\ ${ }^{3}$ Department of Chemistry and Biochemistry, CCS HAU Hisar, India \\ *Corresponding author
}

\author{
A B S T R A C T
}

\section{Ke y w o r d s \\ Pearl millet, Crude protein, Total antioxidant activity, Micronutrient, Phytate.}

\section{Article Info}

Accepted:

10 February 2017

Available Online:

10 March 2017
Protein, micronutrient, antioxidant potential, polyphenols and phytate content of popular hybrids and composites of pearl millet has been estimated for two consecutive seasons. Crude protein content of pearl millet hybrids and composites analyzed varied from 9.49 to 13.09 and 9.05 to $14.73 \%$, Fe content from 39 to 66 and 22 to $75 \mathrm{mg} / \mathrm{kg}$, Zn content from 32 to 49 and 21 to $56 \mathrm{mg} / \mathrm{kg}$, polyphenols from 210 to $297 \mathrm{mg} / 100 \mathrm{~g}$ and 221 to 345 $\mathrm{mg} / 100 \mathrm{~g}$, and phytate content from 4.74 to 6.29 and 5.54 to $6.67 \mathrm{mg} / \mathrm{g}$ during kharif-2013 and kharif-2014, respectively. Similarly total antioxidant activity of these genotypes ranged from 732 to 1231 and 884 to $1189 \mu \mathrm{g}$ vitamin C equi./g as DPPH scavenging capacity and 3592 to $4884 \mu \mathrm{g}$ trolox equi./g as $\mathrm{ABTS}^{+}$scavenging capacity. Tested nutritional characters of these hybrids/composites were not affected to an appreciable extent by the growing season. TAA of all the tested genotypes was higher than that of commercial samples of wheat $(550 \mu \mathrm{g}$ vitamin $\mathrm{C}$ equi./g) and maize $(680 \mu \mathrm{g}$ vitamin $\mathrm{C}$ equi./g). The widely adopted and most popular short duration hybrid HHB 67 imp possessing high protein $(12.39 \%)$ and moderate $\mathrm{Fe}(60 \mathrm{mg} / \mathrm{kg})$ contents and dual purpose composite variety HC 10 with high contents of protein $(12.36 \%)$ as well as Fe $(71 \mathrm{mg} / \mathrm{kg})$ are well suited for nutritional security of part of the population of Haryana and neighboring states consuming pearl millet as staple food.

\section{Introduction}

Plant-based food products are the main staple food for human beings in many parts of the world. They constitute an important source of carbohydrates, protein, dietary fiber, vitamins and anti-nutrients (Katina et al., 2005). Pearl millet [Pennisetum glaucum (L) R. Br.] is an important hardy coarse cereal crop grown mostly in marginal environments in the arid and semi-arid tropical regions of south Asia and sub-saharan Africa. Pearl millet, being a
C4 plant, has a very high photosynthetic efficiency and dry matter production capacity. It is usually grown under most adverse agroclimatic conditions where other crop fails to produce economic yields. In spite of this, pearl millet has a remarkable ability to respond to favorable environments because of its short developmental stages and capacity for higher growth rates, thus making it excellent crop in short growing season under 
improved crop management. Therefore, pearl millet is a central component of the food and fodder security of the rural poor in dry areas with very limited rainfall. In India, it is grown over an area of 7.90 million hectares with total production of 9.20 million tones and productivity of 1.16 tones/ha (Anonymous, 2013). The major pearl millet growing states in order of area are Rajasthan, Maharashtra, Gujarat, Uttar Pradesh and Haryana. These states account for $87 \%$ of the total area under cultivation. In Haryana, area under this crop during kharif-2013-14 was 4.04 lakh hectare, with total production of 8.31 lakh tones and productivity of 2.06 tones/ha (Anonymous, 2014).

Health benefits associated with the consumption of millets have been documented. Their antioxidant and antimicrobial properties have been reported (Varsha et al., 2009; Chandrasekara and Shahidi, 2011; Chethan and Malleshi, 2007). Phenolic extracts from millets have been reported to inhibit intestinal $\alpha$-glucosidase and pancreatic $\alpha$-amylase, and may play a vital role in the management of postprandial hyperglycemia (Shobana et al., 2009) and wound healing properties has been reported (Hegde et al., 2005). Pearl millet supplies energy equivalent to $360 \mathrm{kcal} / 100 \mathrm{~g}$ (Aykroyd, 1951). Singh et al., (2010) however, reported $2900 \mathrm{kcal}$ metabolizable energy of pearl millet. The starch content of pearl millet grain ranges from 62.8 to $70.5 \%$, amylose from 21.9 to $28.8 \%$, soluble sugars from 1.4 to $2.6 \%$ and reducing sugars from 0.1 to $0.26 \%$ (Abdella et al., 1998). Protein content in pearl millet as low as $6.4 \%$, and as high as $24 \%$ has been reported by many investigators (Abdella et al., 1998; Anonymous, 2013). Grain protein content of pearl millet hybrids and varieties released in India ranges between 8.00 to $13.00 \%$ (Anonymous, 2013). Pearl millet is also a good source of fat having about 5.0 to $7.5 \%$ lipids (Goyal et al., 2014). It is free from major anti-nutrients but contain variable amount of phenolics and phytate (Goyal et al., 2014; Lestienn et al., 2005). Antioxidants in cereals have the advantage of keeping their antioxidant capacity inside the human body too, and not only in the plant have they derived from (Serea and Barna, 2011). Bran, a byproduct of milling has antioxidant potential due to phenolic acids such as p-coumaric acid and vanillic acids that are concentrated in the bran portion of cereal kernels. Antioxidant activity of five bran extracts exhibited appreciable levels of total phenolics, flavonoids and DPPH radical scavenging activities (Iqbal et al., 2007). Reports on antioxidant activity of pearl millet however, are scanty. Ilesanmi and Akinloye (2013) observed appreciable amount of DPPH scavenging activity of pearl millet. Pushparaj and Urooj, (2014) demonstrated that antioxidant activity of pearl millet was influenced both by the processing methods and the cultivars. Fibre content in pearl millet has been reported to be $1.6 \mathrm{~g} / 100 \mathrm{~g}$ (Malleshi et al., 1986).

Though mineral profile of pearl millet is also better than other cereals but bioavailability of bivalent minerals like $\mathrm{Fe}, \mathrm{Mg}$ etc. is low in pearl millet due to presence of some inherent factors like phytate (Raboy, 2009). Pearl millet contains $300 \mathrm{mg} / 100 \mathrm{~g}$ to $825 \mathrm{mg} / 100 \mathrm{~g}$ phytate (Reddy, 2002; Lestienn et al., 2005). A recent study showed that pearl millet accounts for $50 \%$ of the cereal consumption in some of the pearl millet growing areas of India, and it is the cheapest source of grain iron and zinc as compared to other cereals and vegetables (Parthasarathy Rao et al., 2006). Recently, Fe bio-fortified composite ICTP 8203 has been released as ICTP 8203 Fe10-2 with a common name Dhanshakti by ICRISAT. Consumption of $200 \mathrm{~g}$ of pearl millet variety Dhanshakti $(70 \mathrm{mg} / \mathrm{kg}$ Fe and $40 \mathrm{mg} / \mathrm{kg} \mathrm{Zn}$ ) can meet $82 \%$ of the 
recommended daily allowance (RDA) of $\mathrm{Fe}$ in adult man $(17 \mathrm{mg})$ and $66 \%$ of the RDA of non-pregnant and non lactating (NPNL) women $(21 \mathrm{mg})$ in India. It can also meet $66 \%$ of the RDA of $\mathrm{Zn}(12 \mathrm{mg})$ in men and $80 \%$ of the RDA in NPNL women $(10 \mathrm{mg})$, based on the assumption of $5 \%$ bioavailability of $\mathrm{Fe}$ and $25 \%$ bioavailability of $\mathrm{Zn}$ content (ICRISAT, 2013). Keeping these views in mind the present investigation was carried out to explore the nutritional status of the pearl millet hybrids and composites, intensely adopted by farmers of Haryana as well as neighboring districts of Rajasthan, Uttar pardesh and Punjab.

\section{Materials and Methods}

\section{Plant materials}

Grain samples of popular pearl millet [Pennisetum glaucum (L.) R. Br.] seven hybrids (HHB 67 Improved, HHB 94, HHB 146, НHB 197, НHВ 223, НHB 226, НHВ 234) and four composites (WHC 901-445, HMP 802, HC 10, HC 20) widely adopted for cultivation by farmers of Haryana, grown during kharif-2013 and kharif-2014 were procured from Bajra Section, Department of Genetics and Plant Breeding, Chaudhary Charan Singh Haryana Agricultural University, Hisar. The grain samples freed of extraneous matter were stored at ambient temperature for further use. The flour was prepared with flour mill and sieved through 30 micron mesh sized sieve and this flour was used for all the estimations.

\section{Crude protein}

Crude protein content of the pearl millet grain was calculated by multiplying percent nitrogen by a factor 6.25. Nitrogen was estimated by following Micro-Kjeldahl's method (AOAC, 1990).

\section{Total antioxidant activity}

Total antioxidant activity (TAA) was estimated by following the methods described by Brand-Williams et al., (1995). For TAA determination, $500 \mathrm{mg}$ ground sample was extracted in $10 \mathrm{ml}$ ethanol $(95 \%, \mathrm{v} / \mathrm{v})$ for four hours on a shaker in tight caped plastic bottles. After that centrifuged (Remi CPR-24) the content at $10000 \mathrm{rpm}$ for 10 minute and collected the supernatant and made up the final volume to $10 \mathrm{ml}$ with ethanol $(95 \%$, v/v). For estimation DPPH scavenging capacity, took $200 \mu \mathrm{l}$ of the supernatant and added $300 \mu \mathrm{l}$ of water and $2.5 \mathrm{ml}$ of $0.006 \%$ (w/v) DPPH solution, incubated it under dark for 30 minute. Absorbance was recorded on a UV-Vis spectrophotometer (Thermo Scientific, EVOLUTION 201) at $517 \mathrm{~nm}$. A blank was also run simultaneously without extract. Ascorbic acid standard (5 to $30 \mu \mathrm{g}$ ) was used for calculating TAA in terms of Vitamin C equi./g.

\section{Micronutrients (Fe and $\mathrm{Zn}$ )}

$\mathrm{Fe}$ and $\mathrm{Zn}$ were estimated by Energy Dispersive X-rays fluorescence (EDXRF), at ICRISAT Patancheru, Hyderabad, method described by Paltridge et al., (2012).

\section{Polyphenols}

Polyphenols content was estimated by following the method of Malik and Singh, (1980). Weighed exactly $1 \mathrm{~g}$ dry flour and ground it with a mortar and pestle in $10 \mathrm{ml}$ of $80 \% \quad(\mathrm{v} / \mathrm{v})$ ethanol and centrifuged the homogenate at $10,000 \mathrm{rpm}$ for 10 minutes. The supernatant was collected and reextracted the residue twice with five $\mathrm{ml} 80 \%$ $(v / v)$ ethanol. Pooled the supernatants and made final volume to $15 \mathrm{ml}$. Took one $\mathrm{ml}$ of the supernatant and made up the final volume to $4.0 \mathrm{ml}$ with distilled water. Then added 0.5 $\mathrm{ml}$ of $1 \mathrm{~N}$ Folin-Ciocalteau reagent and then 
after three minutes, $2 \mathrm{ml}$ of saturated $\mathrm{Na}_{2} \mathrm{CO}_{3}$ solution was added to each tube. The contents were mixed thoroughly and placed the tube in boiling water bath for exactly one minute. Tubes were cooled and absorbance was recorded on UV-Vis spectrophotometer (Thermo Scientific, EVOLUTION 201) at $650 \mathrm{~nm}$ against a reagent blank. A standard curve prepared using different concentrations of catechol $(0-100 \mathrm{mg} / \mathrm{ml})$ was used to calculate polyphenol content. Results are expressed as mg catechol equi./100 g dry flour.

\section{Phytate}

Phytic acid was determined by employing the method of Haug and Lantgsch, (1983). Finely ground sample $(500 \mathrm{mg})$ was extracted with $25 \mathrm{ml}$ of $0.2 \mathrm{~N} \mathrm{HCl}$ for 3 hours with continuous shaking on orbital shaker. After proper shaking it was filtered through whatman No. 1 filter paper.

The filtrate was used for phytate estimation. An aliquot $(0.5 \mathrm{ml})$ of above filtrate was taken in a test tubes and $0.9 \mathrm{ml}$ distilled water was added. To all the tubes $1 \mathrm{ml} 0.02 \%$ ferric ammonium sulphate solution (prepared in $0.2 \mathrm{~N} \mathrm{HCl}$ ) was added and then placed in a boiling water bath for 30 minute. Cooled the tubes and one ml of cooled mix transferred to another test tube and to that $1.5 \mathrm{ml}$ of $1 \%$ bipyridine solution was added. The absorbance was measured UV-Vis spectrophotometer (Thermo Scientific, EVOLUTION 201) at $519 \mathrm{~nm}$ against distilled water blank. Phytate content was calculated by using standard curve of sodium phytate $(200 \mu \mathrm{g} / \mathrm{ml})$.

All the estimation were done in three replicates and the data were statistically analyzed in completely randomized design for calculating CD using software 'Statistical Package for Agriculture Scientists', OPSTAT (www.hau.ernet.in).

\section{Results and Discussion}

\section{Proteins}

Average crude protein content of hybrids and composites was $12.16 \%$ which ranged from $9.74 \%$ (HHB 146) to $13.24 \%$ (WHC 901445) during kharif-2013 (Table 1). In this group composites had higher protein content than that of hybrids. For example among hybrids highest protein content $(12.55 \%)$ was present in grains of HHB 226 while in those of WHC 901-445 and HMP 802, the protein content was $13.24 \%$ and $13.07 \%$ respectively. Similar trend in protein content of hybrids and composites was discerned when grown during kharif-2014. Thus, protein content varied from 9.05 to $14.73 \%$ with an average value of $11.81 \%$, which was slightly lower than that was determined in grains produced during kharif-2013 (Table 1). The hybrid HHB 67 improved and the composite WHC 901-445 had highest crude protein content grown during kharif-2014 as well. On the basis of mean of both the seasons, protein content of HHB 67imp and HHB 234 was highest (12.39\%, in each) whereas that of HHB 146 was lowest among the hybrids. In pearl millet, the crude protein content ranging from $6-21 \%$ has been reported (Serna-Saldivar et al., 1991; Baniwal et al., 2003). On the contrary, a lower variation in crude protein content $(9-15 \%)$ in pearl millet genotypes was also reported (Goswami et al., 1970). From a nutrition point of view, high protein pearl millet varieties are much preferred compared with varieties lower in protein content in-spite of the negative correlation between protein concentration and protein quality (Singh et al., 1987).

\section{Micronutrients (Fe and Zn)}

In contrast to the extent of variation in other parameters, a higher magnitude of variation in 
Fe content was observed. Hybrids/composites differed in respect of Fe content varying from 39 to $66 \mathrm{mg} / \mathrm{kg}$ with an average value of 47 $\mathrm{mg} / \mathrm{kg}$ during kharif-2013, and from 22 to $75 \mathrm{mg} / \mathrm{kg}$ with an average value of $55 \mathrm{mg} / \mathrm{kg}$ during kharif-2014 (Table 1). On the basis of both season's average Fe content of hybrids and composites, HHB $67 \mathrm{Imp}(60 \mathrm{mg} / \mathrm{kg})$ amongst the hybrids and $\mathrm{HC} 10(71 \mathrm{mg} / \mathrm{kg})$ followed by WHC 901-445 (67mg/kg) amongst the composites were found superior. The hybrids and composites also varied significantly in grain $\mathrm{Zn}$ content but to a lesser extent than that of $\mathrm{Fe}$ content. Mean $\mathrm{Zn}$ content of these genotypes varied from 27 $\mathrm{mg} / \mathrm{kg}$ to $51 \mathrm{mg} / \mathrm{kg}$ grains. HHB $67 \mathrm{Imp}$. (51 $\mathrm{mg} / \mathrm{kg})$, HC $20(49 \mathrm{mg} / \mathrm{kg})$ and WHC 901$445(49 \mathrm{mg} / \mathrm{kg})$ were superior to the other hybrids and composites in respect of $\mathrm{Zn}$ content (Table 1). Overall, micronutrients profile of HHB $67 \mathrm{Imp}(60 \mathrm{mg} / \mathrm{kg} \mathrm{Fe}$ and 51 $\mathrm{mg} / \mathrm{kg} \mathrm{Zn}$ ), WHC 901-445 (67 mg/kg Fe and $49 \mathrm{mg} / \mathrm{kg} \mathrm{Zn})$ and HC 10 (71 mg/kg Fe and $48 \mathrm{mg} / \mathrm{kg} \mathrm{Zn}$ ) was better than the others. The screened pearl millet hybrids and composites varied significantly in respect of contents of both the micronutrients ( $\mathrm{Fe}$ and $\mathrm{Zn}$ ), raised during both the seasons. A strong positive correlation was observed between $\mathrm{Fe}$ and $\mathrm{Zn}$ contents with correlation coefficient of 0.776 , $\mathrm{P}<0.01$ (Table 3). These results are comparable with the earlier reports. Velu et al., (2007, 2008) reported a large variability for grain $\mathrm{Fe}$ and $\mathrm{Zn}$ content in pearl millet, involving inbred lines, improved open pollinated varieties and germplasm. Nithya $e t$ al., (2006) reported 86ppm and 88ppm Iron and 52ppm and $41 \mathrm{ppm}$ zinc content in traditional (Co7) and hybrid (Cohcu-8) pearl millet varieties respectively. Abdella et al., (1998) also reported 10 to $66 \mathrm{mg} / \mathrm{kg} \mathrm{Fe}$ and 53 to $70 \mathrm{mg} / \mathrm{kg} \mathrm{Zn}$ in pearl millet varieties. Recently, Fe biofortified composite ICTP 8203 has been released as ICTP 8203 Fe10-2 with a common name Dhanshakti by ICRISAT (2013). Finkelstein et al., (2015) has reported improved bioavailability of $\mathrm{Fe}$ as well as $\mathrm{Zn}$ in school going children on consuming biofortified pearl millet Dhanshakti.

\section{Total antioxidant activity}

TAA of hybrids/composites during kharif2013 varied from 732 (WHC 901-445) to $1231 \mu \mathrm{g}$ Vitamin C equi./g (HHB 223) with an average value of $1014 \mu \mathrm{g}$ Vitamin $\mathrm{C}$ equi./g (Table 2). HHB 94 (1138 $\mu \mathrm{g}$ Vitamin C equi./g), HHB 226 (1128 $\mu \mathrm{g}$ Vitamin C equi./g), HHB 197 (1106 $\mu \mathrm{g}$ Vitamin C equi./g) among the hybrids and HMP 802 (1093 $\mu \mathrm{g}$ Vitamin $\mathrm{C}$ equi./g) among the composites had fairly good TAA (Table 2). Qualitatively and quantitatively, almost similar antioxidant activity of the hybrids/composites was discerned during kharif-2014 with both the methods of estimation. Thus, during kharif-2014 TAA of hybrids/composites varied from 884 to 1189 $\mu \mathrm{g}$ Vitamin $\mathrm{C}$ equi./g with an average value of $1055 \mu \mathrm{g}$ Vitamin $\mathrm{C}$ equi./g. Mean of TAA of the hybrids/composites grown during kharif2013 and kharif-2014 indicated that except HHB 67imp and WHC 901-445 (both had lower activity) all the tested genotypes in this category demonstrated excellent antioxidant capacity. Berwal et al., (2016) reported a wide variation in pearl millet total antioxidant activity from 332 to $1529 \mu \mathrm{g}$ Vitamin C equi./g (DPPH scavenging capacity) and 3970 to $6804 \mu \mathrm{g}$ Trolox equi./g (ABTS+ methods) when studied the pearl millet germplasm. Pushparaj and Urooj, (2014) demonstrated that antioxidant activity of pearl millet was influenced both by the processing methods and the cultivars. They also reported a positive correlation between TAA (DPPH scavenging capacity) and flavonoid content of pearl millet grains. Ilesanmi and Akinloye, (2013) observed appreciable amount of DPPH scavenging activity of pearl millet. Pushparaj and Urooj, (2014) reported in pearl millet that 
bran rich fraction showed high antioxidant activity which was due to the tannin, phytic acid and flavonoid levels. Antioxidant activity of five bran extracts exhibited appreciable levels of total phenolics, flavonoids and DPPH radical scavenging activities (Iqbal et al., 2007). The TAA of pearl millet genotypes determined by DPPH method (vitamin C equivalent) and ABTS+ methods (Trolox equivalent) showed significant positive correlation with a correlation coefficient of 0.623 (Table 3). Different studies also showed the similar relationship in DPPH and ABTS+ dependant antioxidant potentials. Dudonne et al., (2009) also reported a strong positive correlation between ABTS and DPPH assay with a Pearson correlation coefficient of $r=$ $0.906, p<0.001$ when used for 30 aqueous plants extracts.

\section{Total polyphenols}

Among all the groups analyzed hybrids/composites had lowest average polyphenols content $254 \mathrm{mg} / 100 \mathrm{~g}$ and 273 $\mathrm{mg} / 100 \mathrm{~g}$, respectively, tested during kharif2013 and kharif-2014 (Table 2). Average polyphenols content of the hybrid HHB 197 (315 $\mathrm{mg} / 100 \mathrm{~g})$ was maximum among the hybrids as well as composites followed by HHB 94 (306 mg/100 g), HHB 223 (282 $\mathrm{mg} / 100 \mathrm{~g})$ and HHB $226(272 \mathrm{mg} / 100 \mathrm{~g})$. HHB 67 Improved among the hybrids and HC 10 and $\mathrm{HC} 20$ amongst the composites possessed comparatively low polyphenols contents.

Table.1 Crude protein, total phenol and micronutrient content of pearl millet hybrids and composites developed at CCS HAU Hisar

\begin{tabular}{clccccccccc}
\hline \multirow{2}{*}{ S.No. } & \multirow{2}{*}{ Pedigree } & \multicolumn{3}{c}{ Crude Protein (\%) } & \multicolumn{3}{c}{ Fe (mg/kg) } & \multicolumn{3}{c}{ Zn (mg/kg) } \\
\cline { 3 - 10 } & & K-13 & K-14 & Mean & K-13 & K-14 & Mean & K-13 & K-14 & Mean \\
\hline $\mathbf{1}$ & HHB-67 Imp & 11.78 & 12.99 & 12.39 & 54 & 65 & 60 & 49 & 52 & 51 \\
$\mathbf{2}$ & HHB-94 & 11.42 & 11.3 & 11.36 & 39 & 44 & 40 & 47 & 44 & 46 \\
$\mathbf{3}$ & HHB-146 & 9.49 & 9.05 & 9.27 & 43 & 49 & 46 & 34 & 38 & 36 \\
$\mathbf{4}$ & HHB-197 & 11.22 & 10.97 & 11.10 & 40 & 47 & 44 & 35 & 32 & 34 \\
$\mathbf{5}$ & HHB-223 & 12.24 & 10.59 & 11.42 & 49 & 48 & 49 & 37 & 42 & 40 \\
$\mathbf{6}$ & HHB-226 & 12.55 & 11.36 & 11.96 & 44 & 49 & 47 & 40 & 49 & 45 \\
$\mathbf{7}$ & HHB-234 & 12.26 & 12.51 & 12.39 & 39 & 54 & 47 & 43 & 37 & 40 \\
$\mathbf{8}$ & WHC-901-445 & 13.09 & 14.73 & 13.91 & 61 & 72 & 67 & 48 & 50 & 49 \\
$\mathbf{9}$ & HMP-802 & 13.07 & 13.11 & 13.09 & 41 & 22 & 32 & 32 & 21 & 27 \\
$\mathbf{1 0}$ & HC-10 & 12.49 & 12.22 & 12.36 & 66 & 75 & 71 & 39 & 56 & 48 \\
$\mathbf{1 1}$ & HC-20 & 12.82 & 11.84 & 12.33 & 45 & 70 & 58 & 45 & 52 & 49 \\
\hline & Mean & $\mathbf{1 2 . 1 6}$ & $\mathbf{1 1 . 8 1}$ & & $\mathbf{4 7}$ & $\mathbf{5 5}$ & & $\mathbf{4 1}$ & $\mathbf{4 3}$ & \\
\hline & C.D. $(\mathbf{p}<\mathbf{0 . 0 5})$ & $\mathbf{0 . 5}$ & $\mathbf{0 . 4 6}$ & & $\mathbf{4 . 1 4}$ & $\mathbf{3 . 8 6}$ & & $\mathbf{3 . 1 8}$ & $\mathbf{3 . 0 4}$ & $\mathbf{1 . 5 8}$ \\
& SE(d) & $\mathbf{0 . 2 2 4}$ & $\mathbf{0 . 2 3}$ & & $\mathbf{1 . 8 6}$ & $\mathbf{2 . 0 5}$ & & $\mathbf{1 . 4 6}$ & $\mathbf{3 . 2 6}$ \\
& C.V. $(\boldsymbol{\%})$ & $\mathbf{1 . 1 0 6}$ & $\mathbf{1 . 8 4}$ & & $\mathbf{3 . 9 4}$ & $\mathbf{4 . 2 8}$ & & $\mathbf{3 . 5 1}$ & $\mathbf{3 . 2 6}$ \\
\hline
\end{tabular}

*K-13= Kharif 2013, K-14=Kharif 2014 
Table.2 Total antioxidant activity and phytate content of pearl millet hybrids and composites developed at CCS HAU Hisar

\begin{tabular}{|c|c|c|c|c|c|c|c|c|c|c|c|}
\hline \multirow{2}{*}{$\begin{array}{l}\text { S. } \\
\text { No }\end{array}$} & \multirow[b]{2}{*}{ Pedigree } & \multicolumn{3}{|c|}{$\begin{array}{c}\text { TAA (DPPH) }(\mu \mathrm{g} \text { vit.C } \\
\text { equi./g) }\end{array}$} & \multirow{2}{*}{$\begin{array}{c}\text { TAA } \\
\left(\text { ABTS }^{+}\right) \\
(\mu g \\
\text { Trolox } \\
\text { equi./g) }\end{array}$} & \multicolumn{3}{|c|}{$\begin{array}{c}\text { Total Polyphenol (mg } \\
\text { catechol equi/100g) }\end{array}$} & \multicolumn{3}{|c|}{ Phytate (mg/g) } \\
\hline & & K-13 & K-14 & Mean & & K-13 & K-14 & Mean & K-13 & K-14 & Mean \\
\hline 1 & HHB-67 Imp & 979 & 884 & 932 & 4110 & 210 & 243 & 227 & 5.9 & 6.54 & 6.22 \\
\hline 2 & HHB-94 & 1138 & 1100 & 1119 & 4252 & 297 & 283 & 306 & 5.82 & 5.74 & 5.78 \\
\hline 3 & HHB-146 & 994 & 1124 & 1059 & 4728 & 262 & 255 & 259 & 6.15 & 5.65 & 5.9 \\
\hline 4 & HHB-197 & 1106 & 1059 & 1083 & 4170 & 284 & 345 & 315 & 6.29 & 5.85 & 6.07 \\
\hline 5 & HHB-223 & 1231 & 1021 & 1126 & 4354 & 254 & 310 & 282 & 6.24 & 6.05 & 6.15 \\
\hline 6 & HHB-226 & 1128 & 1069 & 1099 & 4367 & 258 & 286 & 272 & 6.23 & 5.69 & 5.96 \\
\hline 7 & HHB-234 & 942 & 1119 & 1031 & 4721 & 249 & 240 & 245 & 6.05 & 5.54 & 5.8 \\
\hline 8 & WHC-901-445 & 732 & 884 & 808 & 3592 & 243 & 305 & 274 & 5.79 & 6.67 & 6.23 \\
\hline 9 & HMP-802 & 1093 & 1108 & 1100 & 4616 & 257 & 238 & 269 & 5.98 & 5.78 & 5.88 \\
\hline 10 & $\mathrm{HC}-10$ & 999 & 1189 & 1094 & 4793 & 259 & 221 & 240 & 5.94 & 6.08 & 6.01 \\
\hline 11 & HC-20 & 927 & 1148 & 1038 & 4884 & 223 & 254 & 239 & 4.74 & 6.62 & 5.68 \\
\hline & Mean & 1014 & 1055 & & 4417 & 254 & 273 & & 5.92 & 6.08 & \\
\hline & C.D. $(p<0.05)$ & 52.18 & 73.7 & & 458 & 22.11 & 14.45 & & 0.358 & 0.15 & \\
\hline & $\operatorname{SE}(d)$ & 23.43 & 36.1 & & 226 & 9.927 & 7.1 & & 0.161 & 0.1 & \\
\hline & C.V. $(\%)$ & 2.288 & 3.5 & & 4.43 & 3.908 & 2.38 & & 2.717 & 1.25 & \\
\hline
\end{tabular}

*TAA-Total Antioxidant Activity

Table.3 Pearson correlation matrix among the nutritional parameters

\begin{tabular}{lccccccc}
\hline & Protein & Fe & Zn & TAA (DPPH) & TAA (ABTS) & Phytate & polyphenol \\
\hline Protein & 1 & $0.353^{\mathrm{NS}}$ & $0.291^{\mathrm{NS}}$ & $-0.521^{\mathrm{NS}}$ & $-0.339^{\mathrm{NS}}$ & $0.213^{\mathrm{NS}}$ & $-0.249^{\mathrm{NS}}$ \\
Fe & & 1 & $\mathbf{0 . 7 7 6}^{* *}$ & $-0.570^{\mathrm{NS}}$ & $-0.175^{\mathrm{NS}}$ & $0.418^{\mathrm{NS}}$ & $-0.522^{\mathrm{NS}}$ \\
Zn & & 1 & $-0.459^{\mathrm{NS}}$ & $-0.249^{\mathrm{NS}}$ & $0.176^{\mathrm{NS}}$ & $-0.402^{\mathrm{NS}}$ \\
TAA (DPPH) & & & 1 & $\mathbf{0 . 6 2 3}^{*}$ & $-0.489^{\mathrm{NS}}$ & $0.309^{\mathrm{NS}}$ \\
TAA (ABTS+) & & & & & 1 & $-\mathbf{- 0 . 7 2 4}^{*}$ & $-0.422^{\mathrm{NS}}$ \\
Phytate & & & & & & 1 & $0.059^{\mathrm{NS}}$ \\
Polyphenol & & & & & & 1 \\
\hline
\end{tabular}

*NS- non significant (Significant level @ 5\% level of significance)

The present findings of polyphenol content of pearl millet are in agreement with the earlier reports (Khetarpaul and Chauhan, 1991; Hadimani et al., 1995). They reported the concentration of polyphenols ranging from
608 to $788 \mathrm{mg} / 100 \mathrm{~g}$. A range of $228-486$ $\mathrm{mg} / 100 \mathrm{~g}$ total polyphenols in pearl millet has been reported by Chavan and Hash, (1998). In whole grain, it was $80 \mathrm{mg} / 100 \mathrm{~g}$ the contradictory results reported on polyphenols 
in the reports mentioned above might be due to different extraction methods and/or methods of estimation used or because of different standards used. $\alpha$-glucosidase and pancreatic $\alpha$-amylase inhibition properties of millet phenolics has been reported, therefore, it may play a vital role in the management of postprandial hyperglycemia (Shobana et al., 2009) and wound healing properties has been reported (Hegde et al., 2005). As polyphenols are major component of antioxidant potential but in pearl millet, polyphenols impart grey colour (Reichert, 1979) and limit protein and starch utilization either by binding with proteins or by inhibiting the digestive enzymes especially trypsine and amylase (Singh, 1984; Pawar and Parlikar, 1990). These compounds have also been identified as the agents that cause off odour in pearl millet flour (Reddy et al., 1986). Thus low polyphenols content is desirable in pearl millet.

\section{Phytate}

Phytate content of hybrids/composites grown during kharif-2013 differed from each other within a range of 4.74 (HC 20) to $6.29 \mathrm{mg} / \mathrm{g}$ (HHB 197) with an average phytate equivalent to $5.92 \mathrm{mg} / \mathrm{g}$ of hybrids and composites (Table 2). During kharif-2014 almost similar results were observed for each hybrid and composite in respect of phytate content which varied from 5.54 to $6.67 \mathrm{mg} / \mathrm{g}$ with a mean value of $6.08 \mathrm{mg} / \mathrm{g}$. Mean value of phytate content of the composites HC 20 was slightly lower compared to those of other hybrids and composites because of lower content recorded during kharif-2013. Thus, the selected hybrids and composites are at par in respect of the phytate concentration i.e. all are having high phytate content. These values are corresponded with the earlier reports. Reddy et al., (1986) reported a wide variation in phytic acid content of pearl millet varieties, valued between 0.18 to $1.67 \%$, Kumar and
Chauhan, (1993) also reported $825.7 \mathrm{mg} / 100$ $\mathrm{g}$ phytic acid in pearl millet flour. Lestienne $e t$ al., (2005) reported in Gempela cultivar (yellow colour seeds) of pearl millet flour that phytate and iron binding phenolic compound contents were around $0.633 \mathrm{~g} / 100 \mathrm{~g}$. Reddy, (2002) also reported similar values for phytate content in pearl millet grains. In general, IP6 (inositol hexaphosphate) accumulates in the protein storage bodies as mixed salts called phytate that chelate a number of mineral cations. During the process of germination, endogenous grain phytase is activated, which degrades phytate, releasing stored phosphorus, myo-inositol and bound mineral cations that are further utilized by the developing seedlings (Raboy, 2009). On Pearson matrix negative correlation was observed between phytate content and $\mathrm{ABTS}^{+}$ dependant total antioxidant activity, but we couldn't find any literature showing this type of relationship between phytate and $\mathrm{ABTS}^{+}$ dependant TAA.

In conclusion, all the tested genotypes possess in vitro high antioxidant potential than that of commercial samples of wheat and maize. The widely adopted and most popular short duration hybrid HHB 67 improved possessing high protein $(12.39 \%)$ and moderate $\mathrm{Fe}$ $(60 \mathrm{mg} / \mathrm{kg})$ contents and dual purpose composite variety $\mathrm{HC} 10$ with higher protein $(12.36 \%)$ along with $\mathrm{Fe}(71 \mathrm{mg} / \mathrm{kg})$ are well suited for nutritional security of part of the population of Haryana consuming pearl millet as staple food. Along with these a white grain composite WHC 901-445 also had good nutritional profile with $13.09 \%$ protein, 71 $\mathrm{mg} / \mathrm{kg}$ Fe and $49 \mathrm{mg} / \mathrm{kg}$ Zn content might be an addition to the nutrient rich pearl millet hybrids/composites after its release. Along with nutritional richness, pearl millet is drought and temperature hardy crop which can give potential yield under very marginal soil and weather conditions therefore this crop has the potential to play a vital role in 
providing food as well as nutritional security to the growing world population.

\section{References}

Abdella, A.N., Tinay, A.H., Mohamad, B.E., Abdalla. 1998. Proximate composition, starch, phytate, and mineral contents of 10 pearl millet genotypes. Food Chem., 63(2): 243-246.

Anonymous. 2013. Annual report-2012-13. All India Coordinated Pearl Millet Improvement Project, Jodhpur, Rajasthan, India.

Anonymous. 2014. http://agriharyana.nic.in/ Stat-Info/Final estimates.

AOAC. 1990. Official Methods of Analysis. Association of Official Analytical Chemists, Washington, D.C.

Aykroyd, W.R., Patwardhan, V.N. and Ranganathan, S. 1951. The nutritive value of Indian foods and the lanning of satisfactory diets. Health Bulletin No. $23,4^{\text {th }}$ edition, Ministry of Health, New Delhi, India.

Baniwal, C.R., Sabharwal, P.S., Chugh, L.K. and Yadav, H.P. 2003. A study on protein and fat content of cytoplasmic male sterile lines of pearl millet. In Proc. Natl. Seminar on Processing and Utilization of Millets for Nutritional security, CCS Haryana Agricultural University, Hisar.

Berwal, M.K., Chugh, L.K., Goyal, P. and Kumar, R. 2016. Total Antioxidant Potential of Pearl Millet Genotypes: Inbreds and Designated B-lines. Indian J. Agri. Biochem., 29(2): 201-204. doi 10.5958/0974-4479.2016.00032.0.

Brand-Williams, W., Cuvelier, M.E. and Berset, C. 1995. Use of free radical method to evaluate antioxidant activity. Lebensmittle-Wissenschaft and Technologie, 28: 25-30.

Chandrasekara, A. and Shahidi, F. 2011. Determination of antioxidant activity in free and hydrolysed fractions of millet grains and characterization of their phenolic properties by HPLC-DADESI-MS. J. Functional Foods, 3: 144158.

Chavan, J.K. and Hash, C.T. 1998. Biochemical constituents related to odour generation in some ICRISAT pearl millet materials. ISMN, 39: 151152.

Chethan, S. and Malleshi, N.G. 2007. Isolation and characterization of finger millet polyphenols. Food Chem., 105: 862-870.

Dudonne, S., Vitrax, X., Coutiere, P., Woillez, M., Merillon, J.M. 2009. Comparative study on antioxidant properties and total phenolic content of 30 plant extracts of industrial intrest using DPPH, ABTS, FRAP, SOD and ORAC assay. J. Agri. Food Chem., 57: 1768-1774.

Finkelstein, J.L., Mehta, S., Udipi, A.S., Ghugre, P.S., Luna, S.V., Wenger, M.J., Murray-Kolb, L.E., Przybyszewski, E.M., Haas, J.D. 2015. A Randomized trial of Iron-biofortified pearl millet in school children in India. J. Nutri., 1-6, doi:10.3945/jn.114.208009.

Goswami, A.K., Sehgal, K.L. and Gupta, B.K. 1970. Chemical composition of bajra grains: III. Indian inbreds. The Indian J. Nutrition and Dietetics, 7: 5.

Goyal, P., Chugh, L.K., Dev Vart and Kumar, R. 2014. Elite Inbreds G73-107, HBL 11 and 78/711 for value addition to pearl millet. In National Symposium on Advances in Biotechnology for Crop Improvment. Eternal University, Baru Sahib, Himachal Pradesh, India. July 12. Pp-57.

Hadimani, N.A., Ali, S.Z. and Malleshi, N.G. 1995. Physico-chemical composition and processing characteristics of pearl millet varieties. J. Food Sci. Technol., 2(3): 193-198. 
Haug, W. and Lentzsch, H.J. 1983. Sensitive method for the rapid determination of Phytate in cereals and cereal products. J. Food Sci. Agri., 34: 1423-1426.

Hegde, P.S., Rajasekaran, N.S. and Chandra, T.S. 2005. Effect of antioxidant properties of millet species on oxidative stress and glycemic status in alloxan induced rats. Nutrition Res., 25: 11091120

ICRISAT. 2013. High-iron pearl millet cultivars for better nutrition. News Lett., pp. 1-8.

Ilesanmi, O.K.B. and Akinloye, O.A. 2013. Assessment of nutritional composition and antioxidant ability of pearl millet (Pennisetum glaucum). American $J$. Res. Communications, 1(6): 262-272.

Iqbal, S., Bhanger, M.I. and Anwar, F. 2007. Antioxidant properties and components of bean extracts from selected wheat varieties commercially available in Pakistan. LWT-Food Sci. Technol., 40: 361-367.

Katina, K., Arendt, E., Liukkonen, K.H., Autio, K., Flander, L. and Poutanen, K. 2005. Potential of sourdough for healthier cereal products. Trends Food Sci. Technol., 16: 104-112.

Khetarpaul, N. and Chauhan, B.M. 1991. Effect of pure sequential culture fermentation by yeasts and lactobacilli on HCI-extractability of mineral from pearl millet. Food Chem., 39: 347-355.

Kumar, A. and Chauhan, B.M. 1993. Effect of phytic acid on protein digestibility (in vitro) and $\mathrm{HCl}$-extractability of minerals in pearl millet sprouts. Cereal Chem., 70(5): 504-506.

Lestienne, I. Icard-Verniere, C., Mouquet, C., Picq, C. and Treche, S. 2005. Effects of soaking whole cereal and legume seeds on iron, zinc and phytate contents. Food Chem., 89: 421-425.

Malik, C.P. and Singh, S.B. 1980. In: Plant enzymology and histoenzymology.
Kalyani Publishers, New Delhi, p. 53. Malleshi, N.G., Desikachar, H.S.R. and Venkat Rao, S. 1986. Protein quality evaluation of a weaning food based on malted ragi and green gram. Qual. Plant. Plant Foods for Human Nutrition, 36:223-230.

Nithya, K.S., Ramachandramurty, B. and Krishnamoorthy, V.V. 2006. Assessment of Anti-Nutritional Factors, Minerals and Enzyme Activities of the Traditional (Co7) and Hybrid (Cohcu-8) Pearl Millet (Pennisetum glaucum) as Influenced by Different Processing Methods. J. Appl. Sci. Res., 2(12): 1164-1168.

Paltridge, N.G., Milham, P.J., OrtizMonasterio, J.I., Velu, G., Yasmin, Z., Palmer, L.J., Guild, G.E. and Stangoulis, J.C.R. 2012. Energydispersive X-ray fluorescence spectrometry as a tool for zinc, iron and selenium analysis in whole grain wheat. Plant and Soil, 361: 261-269.

Parthasarathy Rao, P., Birthal, P.S., Reddy, B.V.S., Rai, K.N. and Ramesh, S. 2006. Diagnostics of sorghum and pearl millet based nutrition in India. Int. Sorghum and Millets Newsletter, 47: 93-93.

Pawar, V.D. and Parlikar, G.S. 1990. Reducing the polyphenols and phytate and improving the protein quality of pearl millet by dehulling and soaking. $J$. Food Sci. Technol., 27(3): 140-143.

Pushparaj, F.S. and Urooj, A. 2014 Antioxidant activity in two Pearl Millet (Pennisetum typhoideum) cultivars as influenced by processing. Antioxidants, 3:55-66. doi: 10.3390/antiox3010055.

Raboy, V. 2009. Approaches and challenges to engineering seed phytate and total phosphorus. Plant Sci., 177: 281-296.

Reddy, N.R. 2002. Occurrence, distribution, content, and dietary intake of phytate. In Food phytates; N. R. Reddy and S. K. Sathe, Eds.; CRC Press: Boca Raton, 
FL; pp. 25-51.

Reddy, V.P., Faubion, J.M. and Hoseney, R.C. 1986. Odor generation in ground, stored pearl millet. Cereal Chem., 63(5): 403-406.

Reichert, R.D. 1979. The pH sensitive pigments in pearl millet. Cereal Chem., 56: 291-294.

Serea, C. and Barna, O. 2011. Phenolic content and antioxidant activity in oat. Annals of Food Sci. Technol., 12(2): 164-168.

Serna-Saldivar, S.D., McDonough, C.M. and Rooney, L.W. 1991. The millets. In Handbook of Cereal Science and Technology. (K.J. Lorenz and K. Kulp, eds). New York, Marcel Dekker. pp. 271-300.

Shobana, S., Sreerama, Y.N. and Malleshi, N.G. 2009. Composition and enzyme inhibitory properties of finger millet (Eleusine coracana L.) seed coat phenolics: Mode of inhibition of $\alpha$ glucosidase and pancreatic amylase. Food Chemistry, 115:1268-1273.

Singh, P.U., Singh, B.O., Eggu, K., Kuma, A. and Andrews, D.J. 1987. Nutritional evaluation of high protein genotypes of pearl millet [Pennisetum americanum (L.)]. J. Sci. Food and Agri., 38: 41-48.

Singh, S.D., Sihag, S., Sihag, Z.S. and Chugh, L.K. 2014. Effect of replacing maize with pearl milleton egg production and quality in layers. Indian J. Animal Nutrition, 31(1): 92-96.

Singh, U. 1984. The inhibition of digestive enzymes by polyphenols of chickpea and pigeon pea. Nutrition Reports Int., 29:745.

Varsha, V., Asna, U. and Malleshi, N.G. 2009. Evaluation of antioxidant and antimicrobial properties of finger millet polyphenols (Eleusine coracana). Food Chem., 114: 340-346.

Velu, G., Rai, K.N., Muralidharan, V., Kulkarni, V.N., Longvah, T. and Raveendran, T.S. 2007. Prospects of breeding biofortified pearl millet with high grain iron and zinc content. Crop Improvement, 126:182-185.

Velu, G., Rai, K.N. and Sahrawat, K.L. 2008. Variability for grain iron and zinc content in a diverse range of pearl millet populations. Crop Improvement, 35(2): 186-91.

\section{How to cite this article:}

Berwal, M.K., L.K. Chugh, Preeti Goyal, Ramesh Kumar and Dev Vart. 2017. Protein, Micronutrient, Antioxidant Potential and Phytate Content of Pearl Millet Hybrids and Composites Adopted for Cultivation by Farmers of Haryana. Int.J.Curr.Microbiol.App.Sci. 6(3): 376-386. doi: https://doi.org/10.20546/ijcmas.2017.603.043 